Prepared in cooperation with the North Platte and South Platte Natural Resources Districts

Helicopter Electromagnetic and Magnetic Geophysical Survey Data, Portions of the North Platte and South Platte Natural Resources Districts, Western Nebraska, May 2009

By B.D. Smith, J.D. Abraham, J.C. Cannia, B.J. Minsley, M. Deszcz-Pan, and L.B. Ball

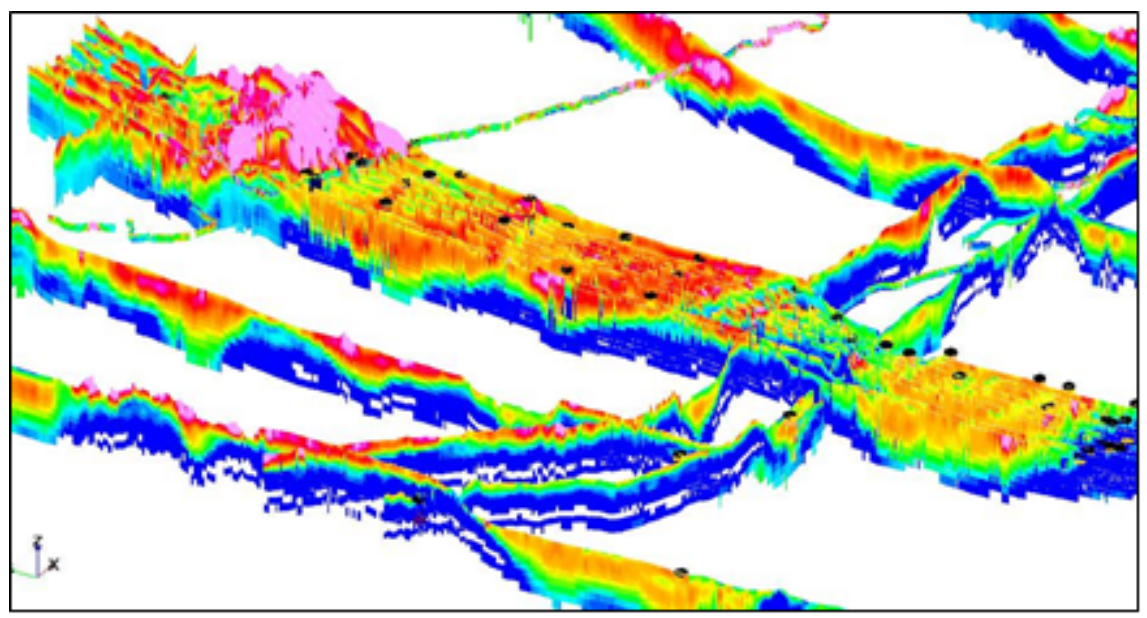

Open-File Report 2010-1259

Version 1.1 
THIS PAGE INTENTIONALLY BLANK 


\section{U.S. Department of the Interior KEN SALAZAR, Secretary}

\section{U.S. Geological Survey Marcia K. McNutt, Director}

\section{U.S. Geological Survey, Reston, Virginia: 2010}

For product and ordering information: World Wide Web: http://www.usgs.gov/pubprod/ Telephone: 1-888-ASK-USGS

For more information on the USGS-the Federal source for science about the Earth, its natural and living resources, natural hazards, and the environment: World Wide Web: http://www.usgs.gov/

Telephone: 1-888-ASK-USGS

Suggested citation:

Smith, B.D., Abraham, J.D., Cannia, J.C., Minsley, B.J., Deszcz-Pan, M., and Ball, L.B., 2010, Helicopter electromagnetic and magnetic geophysical survey data, portions of the North Platte and South Platte Natural Resources Districts, western Nebraska, May 2009: U.S. Geological Survey Open-File Report 2010-1259, 33 p.

Any use of trade, product, or firm names is for descriptive purposes only and does not imply endorsement by the U.S. Government.

Although this report is in the public domain, permission must be secured from the individual copyright owners to reproduce any copyrighted material contained within this report.

Front Cover: 3-D view of the inverted resistivity depth sections along the North Platte River valley. Depth of the sections is about 35 meters and the box is about 8 kilometers wide. 


\section{Contents}

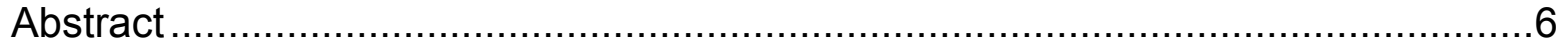

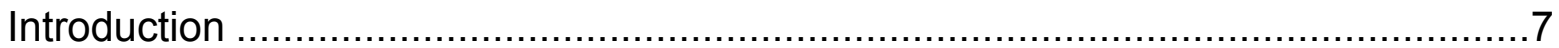

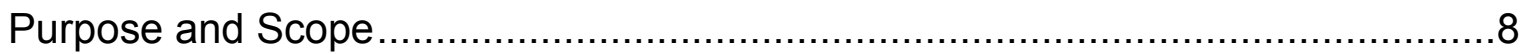

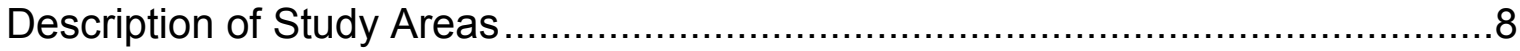

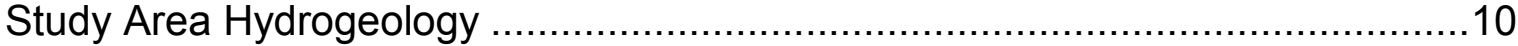

Airborne Geophysical Survey Overview ................................................12

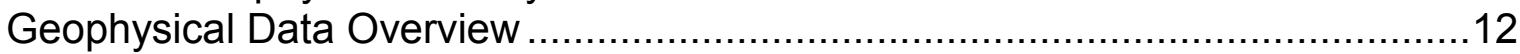

Helicopter Electromagnetic and Magnetic Survey ...........................................14

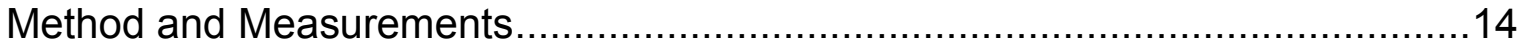

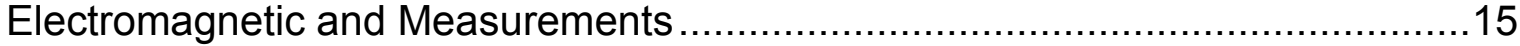

Total Magnetic Field Measurements ...............................................18

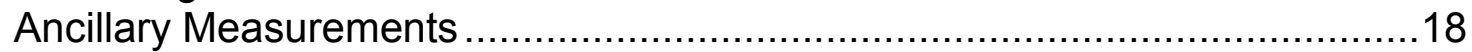

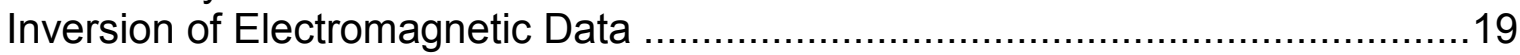

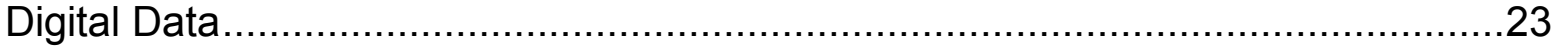

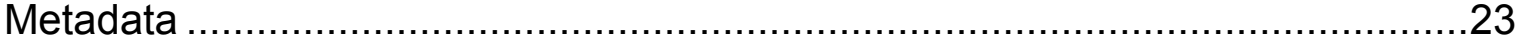

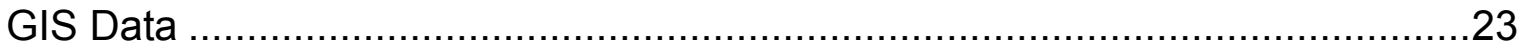

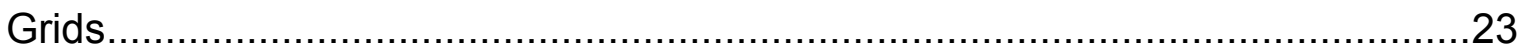

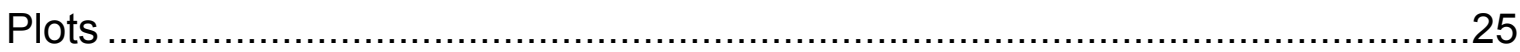

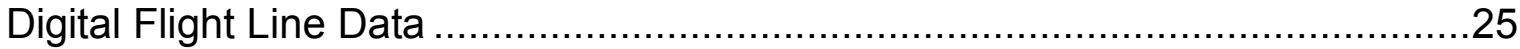

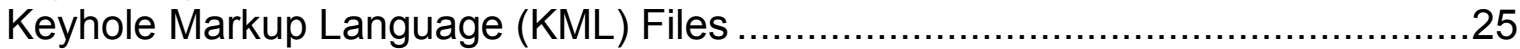

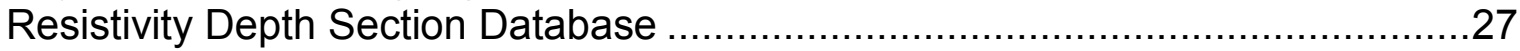

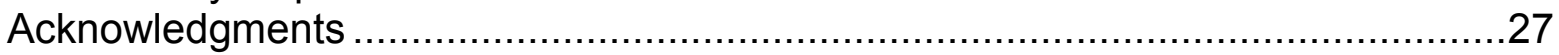

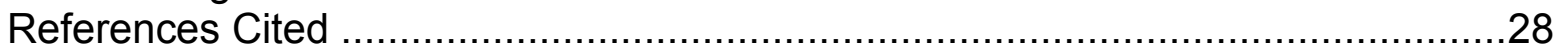

APPENDIX I: American Geophysical Union Poster.........................................31

APPENDIX II: American Geophysical Union Poster..........................................32

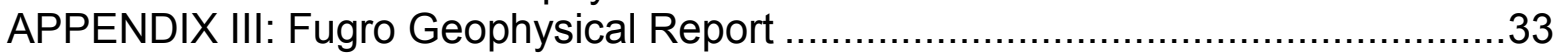

\section{Figures}

1. Location of study area and helicopter electromagnetic and magnetic survey .............. 9

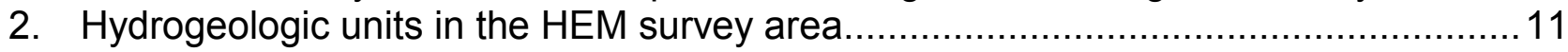

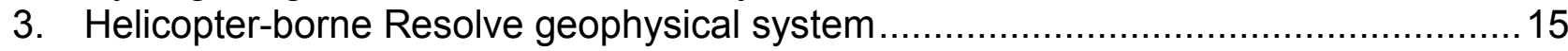

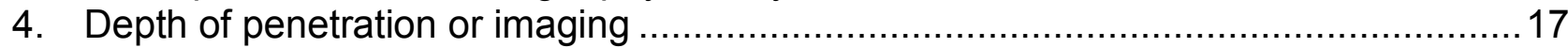

5. Screen shot of ArcMap plot of GEOSOFT grid for the 2008 Morril Block ...................24

6. Screen capture of Google Earth map for the HEM survey in Sidney, Nebraska,

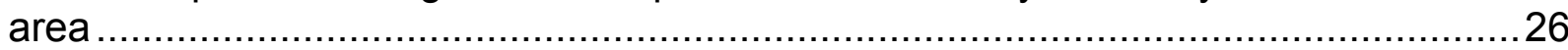

\section{Tables}

1. Digital data organization and description for files and directories ...........................13

2. Flight line direction and spacing for each survey area......................................... 14

3. Frequencies and measurement sensitivities for the HEM survey ............................ 15

4. Fugro-specified data errors for the 2008 and 2009 HEM surveys ...........................20

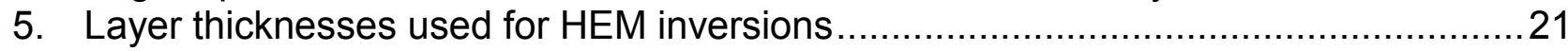

6. Summary inversion parameters for use in EM1DFM ..........................................22 


\section{Conversion Factors, Datum, and Acronyms}

\section{SI to Inch/Pound}

\begin{tabular}{lcl}
\hline \multicolumn{1}{c}{ Multiply } & \multicolumn{1}{c}{ By } & \multicolumn{1}{c}{ To obtain } \\
\hline meter $(\mathrm{m})$ & 3.281 & foot $(\mathrm{ft})$ \\
kilometer $(\mathrm{km})$ & 0.6214 & mile $(\mathrm{mi})$ \\
square kilometer $\left(\mathrm{km}^{2}\right)$ & 247.1 & acre \\
liter $(\mathrm{L})$ & 0.2642 & gallon $(\mathrm{gal})$ \\
nanotesla $(\mathrm{nT})$ & 1 & gamma \\
gram $(\mathrm{g})$ & 0.03527 & ounce, avoirdupois $(\mathrm{oz})$ \\
\hline
\end{tabular}

Temperature in degrees Celsius $\left({ }^{\circ} \mathrm{C}\right)$ may be converted to degrees Fahrenheit $\left({ }^{\circ} \mathrm{F}\right)$ as follows: ${ }^{\circ} \mathrm{F}=\left(1.8 \times{ }^{\circ} \mathrm{C}\right)+32$

Electrical conductivity is given in millisiemens per meter $(\mathrm{mS} / \mathrm{m})$ unless otherwise specified. Electrical resistivity is given in ohm-meters unless otherwise specified. $1 \mathrm{mS} / \mathrm{m}=1000 /$ ( 1 ohm-meter) thus $10 \mathrm{mS} / \mathrm{m}=100$ ohm-meters.

Vertical coordinate information is referenced to the "North American Vertical Datum of 1988 (NAVD 88)" except as noted in text.

Horizontal coordinate information is referenced to the "North American Datum of 1983, Universal Transverse Mercator Zone 13 (NAD 83 UTM Zone 13N)" except as noted in text.

Airborne geophysical survey reference for GPS data is WGS84.

ACRONYMS USED IN THIS REPORT:

EM Electromagnetic

DTM Digital Terrain Model

GPS Global Positioning System

HEM Helicopter Electromagnetic

RTP Reduced-to-Pole

USGS U.S. Geological Survey

UTM Universal Transverse Mercator

ABBREVIATIONS USED IN THIS REPORT:

$\mathrm{Hz} \quad$ hertz

$\mathrm{kHz} \quad$ kilohertz 


\title{
Helicopter Electromagnetic and Magnetic Geophysical Survey Data, Portions of the North Platte and South Platte Natural Resources Districts, Western Nebraska, May 2009
}

By Bruce D. Smith, Jared D. Abraham, James C. Cannia, Burke Minsley, Maria Deszcz-Pan, and Lyndsay Ball

\begin{abstract}
This report is a release of digital data from a helicopter electromagnetic and magnetic survey that was conducted during June 2009 in areas of western Nebraska as part of a joint hydrologic study by the North Platte Natural Resources District (NRD), South Platte NRD, and U.S. Geological Survey (USGS). Flight lines for the survey totaled 937 line kilometers (582 line miles). The objective of the contracted survey, conducted by Fugro Airborne, Ltd., is to improve the understanding of the relation between surface-water and groundwater systems critical to developing groundwater models used in management programs for water resources. A unique aspect of the survey is the flight line layout. One set of flight lines was flown in a zig-zag pattern extending along the length of the previously collected airborne data. The success of this survey design depended on a well-understood regional hydrogeologic framework and model developed by the Cooperative Hydrologic Study of the Platte River Basin and the airborne geophysical data collected in 2008. Resistivity variations along lines could be related to this framework. In addition to these lines, more traditional surveys consisting of parallel flight lines, separated by about 400 meters were carried out for three blocks in the North Platte NRD, the South Platte NRD and in the area of Crescent Lakes. These surveys helped to establish the spatial variations of the resistivity of hydrostratigraphic units. An additional survey was flown over the Crescent Lake area. The objective of this survey, funded by the USGS Office of Groundwater, was to map shallow hydrogeologic features of the southwestern part of the Sand Hills that contain a mix of fresh to saline lakes.
\end{abstract}


The electromagnetic equipment consisted of six different coil-pair orientations that measured resistivity at separated frequencies from about 400 hertz to about 140,000 hertz. The electromagnetic data along flight lines were converted to electrical resistivity. The resulting line data were processed to produce grids and georeferenced maps, which are included with this report. The electrical resistivity data were input into a numerical inversion to estimate resistivity variations with depth. In addition to the electromagnetic data, total field magnetic data and digital elevation data were collected. Data released in this report consist of flight line data, digital grids, digital databases of the inverted electrical resistivity with depth, and digital maps of the apparent resistivity and total magnetic field. The depth range of the subsurface investigation for the electromagnetic survey (estimated as deep as 60 meters) is comparable to the depth of shallow aquifers. The geophysical data and hydrologic information from USGS and cooperator studies are being used by resource managers to develop groundwater resource plans for the area. In addition, data will be used to refine hydrologic models in western Nebraska.

\section{Introduction}

Airborne geophysical studies have been used effectively by the U.S. Geological Survey (USGS) in a variety of groundwater resource projects and programs (Smith and others, 2007). Electrical geophysical methods can be used to image the subsurface of the Earth by using techniques very similar to a medical CAT (computed axial tomography) scan of the human body (Won, 1990). A specific example is the helicopter electromagnetic (HEM) survey conducted for the USGS in the upper Missouri River basin (Poplar, Montana) to study groundwater quality (Smith and others, 2006) in a similar hydrologic setting to parts of Nebraska. Based on the success of these and other groundwater studies using airborne geophysical methods, the USGS received funding from Nebraska State agencies to conduct subsurface airborne resistivity mapping in western Nebraska. The results from the project have been described by Cannia and others (2007). The HEM data for that project have been released as a USGS Open-File Report (Smith and others, 2008a). Based in part on this successful application of the HEM mapping method, funding was obtained to fly HEM in the nonglaciated terrain of western Nebraska beginning in 2008 from the Nebraska Environmental Trust, North Platte Natural Resources District (NPNRD), the South Platte Natural Resources District (SPNRD), USGS Cooperative Hydrology Study, and the University of Nebraska School of Natural Sciences Conservation and Survey Division (CSD). This is a large, multifaceted study requiring successful coordination and planning between multiple levels of government. Public involvement and funding of water-resources studies at the local, State, and Federal levels have been and will continue to be vital to long-term success in improving hydrologic settings and modeling. The results from the first year of this project have been described by Abraham and others (2010). The HEM data for that project have been released as a USGS OpenFile Report (Smith and others, 2009). 
As a result of the 2008 airborne geophysical surveys (Smith and others, 2009), additional surveys were planned to augment the data that were collected in 2008 and to continue to provide information for the groundwater modelers. The NPNRD funded surveys of the North Platte River basin from the Wyoming-Nebraska State line to approximately Bridgeport, Nebraska, including a small survey of an area in the Crescent Lakes National Wildlife Refuge. The SPNRD funded a survey of the Lodgepole Creek basin area, a portion of the Cheyenne Table Lands, and a portion of the South Platte River basin along Western Canal. Figure 1 shows the general location of the HEM survey flight lines. The contract was awarded to Fugro Airborne, Ltd., with technical specifications developed by the USGS. Contract monitoring and data quality assurance were carried out by the USGS. Fiscal management of the contract was by the NPNRD. The digital airborne geophysical data collected along flight lines were processed by the contractor to produce digital databases and digital maps. Additional data processing was done by the USGS, and supplemental maps were produced. The electrical resistivity data were input into a numerical inversion for the recovery of the electrical resistivity structure with depth. These digital line data and maps also are included as part of the digital data release.

\section{Purpose and Scope}

This report presents HEM and magnetic maps and data collected for the USGS by Fugro Airborne, Ltd., from May 5 to 19, 2009, in western Nebraska (the panhandle). The total flight line distance flown was 937 line kilometers (582 line miles). The objective of the survey is to map subsurface hydrogeologic features in order to improve the understanding of the relation between surface-water and groundwater systems critical to developing management programs for water resources. The airborne geophysical survey data can be used to map subsurface electrical and magnetic properties of the Earth that can be related to geologic and hydrologic features. In particular, interpretation of the HEM data will be used to refine aquifer geometry for groundwater and geologic models in the western Platte River basin.

\section{Description of Study Areas}

Surveys in the western Nebraska panhandle were done with flight lines along the North Platte River valley, Lodgepole Creek valley, areas of the Cheyenne Table Lands area, Crescent Lakes National Wildlife Refuge, and a portion of Western Canal along the South Platte River (fig. 1). Widely spaced lines were flown in the North Platte River valley and the Lodgepole Creek valley using a zig-zag flight pattern. The design considerations for this type of flight pattern are given by Smith and others (2010). Three blocks of $400 \mathrm{~m}$ spaced lines were flown near the town of Morrill, Crescent Lakes National Wildlife Refuge, and a portion of the area around Western Canal in the South Platte River valley. 


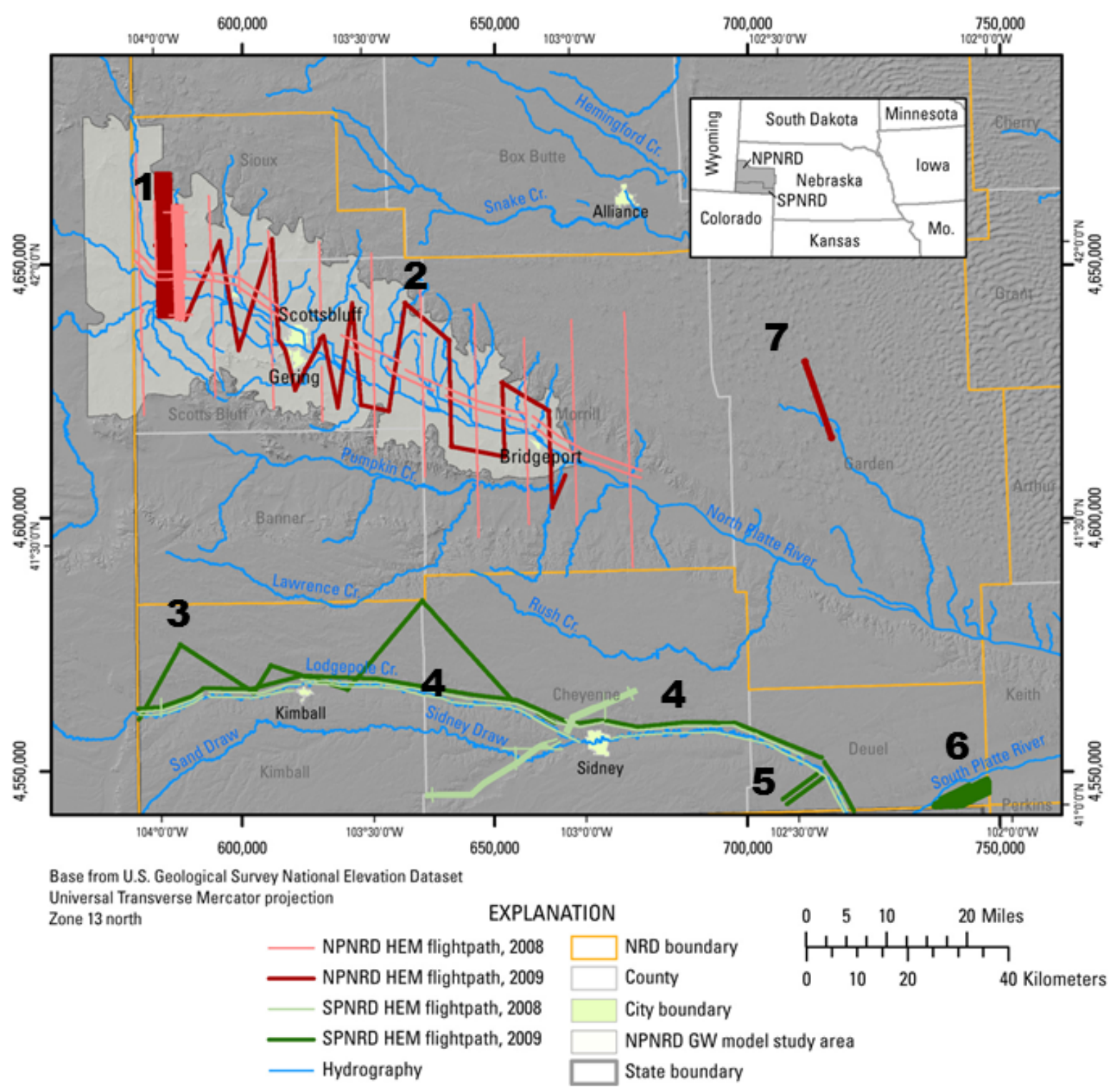

Figure 1. Location of study area and helicopter electromagnetic and magnetic survey in the panhandle of western Nebraska. Numbers are the flight block numbers for the 2009 survey. Line numbers begin with the block number such as 10010,10020, and so on.

The geology consists of Quaternary alluvium, and interbedded Tertiary sandstones and siltstones overlying Cretaceous shale. The Quaternary alluvium makes up the primary aquifer in the North Platte River valley, whereas thin alluvial sediments and Tertiary sandstone channels comprise the primary aquifers in Lodgepole Creek valley. Locally, Tertiary siltstone and Cretaceous shale are weathered and incised (Steele and others, 2007). 


\section{Study Area Hydrogeology}

The hydrogeology of the study area described by Cannia and others (2006) includes the High Plains aquifer (Weeks and others, 1988), which underlies nearly all of the study area and consists of parts of the Brule Formation, the Arikaree Group, the Ogallala Group, and Quaternary deposits (fig. 2).

The Lodgepole Creek part of the study area has been described by Steele and others (2007). The surficial aquifers are Quaternary-age alluvium along Lodgepole Creek, the Tertiary Ogallala Group, and Brule Formation (fig. 2). The three geologic units are separated by two major erosional unconformities. Lodgepole Creek is the predominant watercourse of the SPNRD. Flows are typically ephemeral or intermittent. The largest tributary to Lodgepole Creek, Sidney Draw, is also an ephemeral drainage. Both

drainages were investigated by the airborne geophysical survey described in this report.

The area of Crescent Lakes National Wildlife Refuge lies within the Nebraska Sand Hills, the largest dune sea in the Western Hemisphere (Loope and others, 1995). This area represents a sentinel ecosystem because climate change may lead to the possible mobilization of the dunes, substantial effects on ecosystems, and changes to recharge of the underlying High Plains aquifer. The hydrogeologic setting has been described by Loope and others (1995). The HEM survey was performed along three flight lines from a dune dam south of Crescent Lake and north to Hackberry and Gimlet Lakes. The objective was to map the shallow hydrogeologic features of the southwestern part of the Sand Hills that contain a mix of fresh to saline lakes. The dune dam is defined by a resistive zone that has a depth of 45 meters, suggesting that it influences modern groundwater flow paths and surface-water features. The lakes are defined by low resistivity, which in the case of Gimlet Lake extends to depth. The saline waters may be following a buried paleochannel of ancestral Blue Creek. 


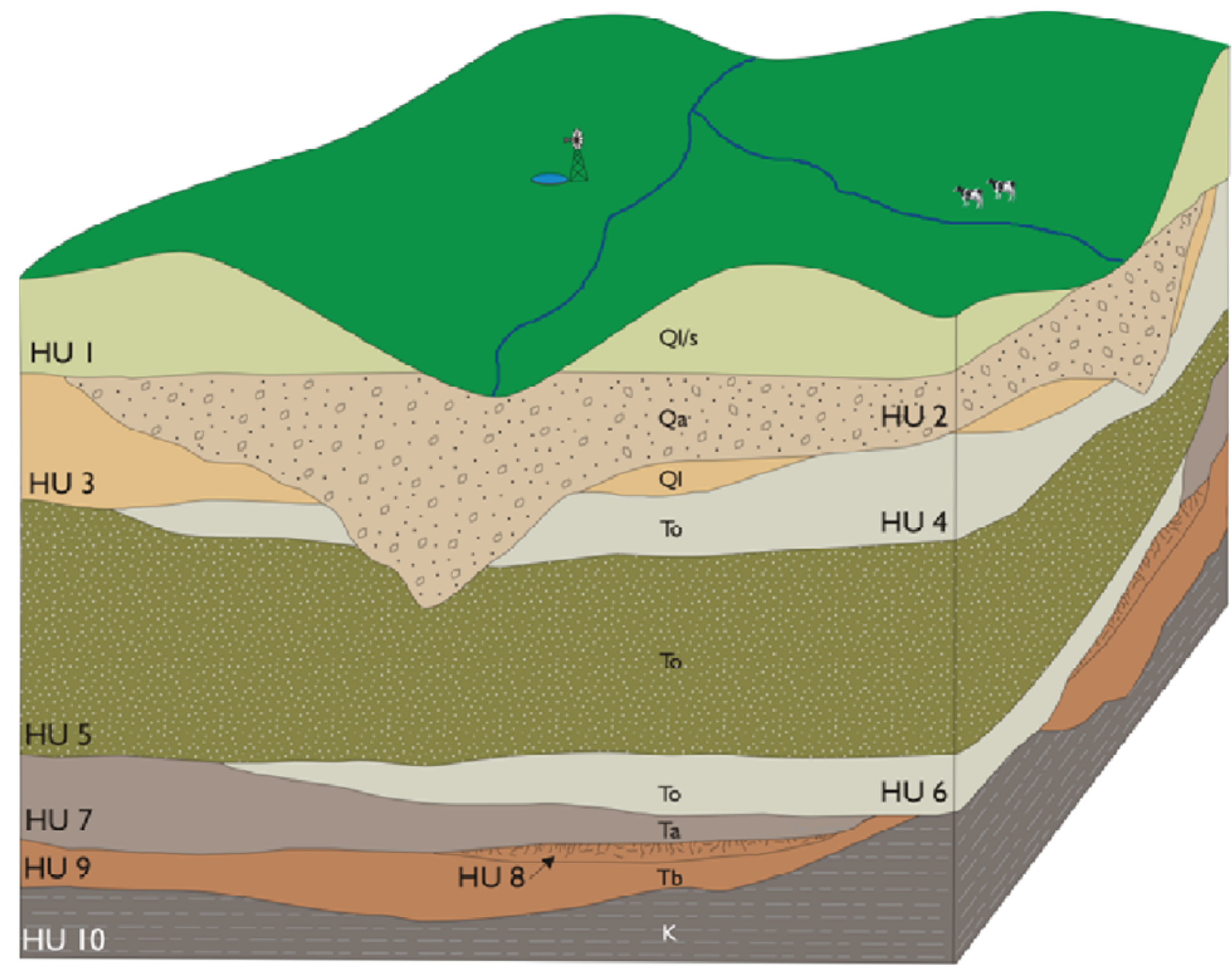

\begin{tabular}{|c|l|c}
\hline Symbol & \multicolumn{1}{|c|}{ Rock unit description } & $\begin{array}{c}\text { Hydrostratigraphic unit } \\
\text { (HU) }\end{array}$ \\
\hline $\mathrm{Q} \mid / s$ & Upper Quaternary fines (loess or dune sand) & 1 \\
\hline$Q_{a}$ & Quaternary alluvial valley fill deposits & 2 \\
\hline $\mathrm{Q} \mid$ & Lower Quaternary fines (loess and silt) & 3 \\
\hline $\mathrm{To}_{\mathrm{o}}$ & Tertiary Ogallala Group (silts and siltstones) & 4,6 \\
\hline $\mathrm{T} 0$ & Tertiary Ogallala Group (sands and sandstones) & 5 \\
\hline $\mathrm{Ta}$ & Tertiary Arikaree Group (sands and siltstones) & 8 \\
\hline $\mathrm{Tb}$ & Tertiary White River Group (fractured Brule Fm., siltstones) & 9 \\
\hline $\mathrm{Tb}$ & Tertiary White River Group (Brule Fm., siltstones and sandstones) & \\
\hline $\mathrm{K}$ & Undifferentiated Cretaceous units (base of aquifer, shales and siltstones) \\
\hline
\end{tabular}

Figure 2. Hydrogeologic units in the HEM survey area (adapted from Cannia and others, 2006). In general, silts, shales, and siltstones tend to be electrically conductive or low resistivity. Dune sands, sandstones, and gravels tend to be electrically resistive. 


\section{Airborne Geophysical Survey Overview}

Management and allocation of water resources in Nebraska are based in part on understanding the relation between surface-water and groundwater systems. To help understand these complex relations, the USGS contracted, in cooperation with State agencies, airborne resistivity, and magnetic (frequency domain helicopter electromagnetic) surveys in eastern Nebraska in 2007 (Smith and others, 2008a, 2008b) and western Nebraska in 2008 (Smith and others, 2009). These surveys were integrated with hydrologic studies (aquifer characteristics and modeling) and ground and borehole geophysical surveys to characterize and map the hydrogeologic framework in three dimensions. The preliminary results of these findings are described by Abraham and others, 2010).

The airborne geophysical survey was structured in three main phases: (1) data acquisition and preliminary processing in the field, (2) final data processing conducted by the contractor (Fugro Airborne, Ltd.) and by the USGS, and (3) interpretation of the processed data including conversion of flight line data to resistivity depth sections. This Open-File Report and the report by the contractor given in Appendix III address the first two phases of the project. The interpretive phase will be ongoing and covered in separate publications and reports. A team of experts is needed in evaluation of the processed data because this evaluation requires an understanding of geophysical methods and hydrogeologic setting (Abraham and others, 2010). The final flight lines flown are shown in figure 1.

\section{Geophysical Data Overview}

The digital data from the airborne survey were acquired and processed by the contractor, Fugro Airborne, Ltd., as described in Appendix II. The USGS did quality control of the contractor's data acquisition, processing, and report. In addition, the USGS did some reprocessing of the data to meet specific requirements of this project. Both the contractor and USGS digital data are included in this data-release report. Table 1 contains links to the digital data and a brief description of the files and directories. 
Table 1. Digital data organization and description for files and folders. The following folder names are hyperlinked to folders in this Open-File Report: METADATA, GIS, GRIDS, LINEDATA, KMZ, PLOTS, REPORT, DEPTHSEC, and CRESCENTLAKE.

\begin{tabular}{|c|c|}
\hline Folder & Description \\
\hline METADATA & Metadata description of digital data by survey block. \\
\hline$\underline{\text { GIS }}$ & $\begin{array}{l}\text { Geographic information consisting of digital raster graphics (DRG) } \\
\text { and survey flight lines (FLIGHT_LINES). The FLIGHT LINE } \\
\text { directory contains subdirectories of autocad files (CAD_DXF) and } \\
\text { shape files (lineSHP). }\end{array}$ \\
\hline$\underline{\text { GRIDS }}$ & $\begin{array}{l}\text { Grids of the electromagnetic and magnetic field data for the } \\
\text { horizontal coplanar coil pairs are in this directory. The grids are in } \\
\text { Geosoft OASIS MONTAJ ( } h t t p: / / m w w \text {.geosoft.com/) format, a } \\
\text { standard of the geophysical industry used in many map display } \\
\text { computer programs. }\end{array}$ \\
\hline LINEDATA & $\begin{array}{l}\text { Flight-line data are in ascii standard and Geosoft OASIS MONTAJ } \\
\text { ( } h \text { ttp://mww.geosoft.com/) database in this directory. The readme } \\
\text { file in this directory contains a description of the channels of the } \\
\text { digital line data. }\end{array}$ \\
\hline$\underline{\mathrm{KMZ}}$ & $\begin{array}{l}\text { This directory contains plots of flight lines and apparent resistivity } \\
\text { maps in keyhole markup language (extension } \mathrm{kmz} \text { ). These files } \\
\text { will plot directly in GOOGLE EARTH (see this report for details). }\end{array}$ \\
\hline$\underline{\text { PLOTS }}$ & $\begin{array}{l}\text { Folder contains geo-TIFF files (UTM13N. NAD83 projected ".tif" } \\
\text { files) of the grids given in the folder GRIDS. Files beginning with } \\
\mathrm{np} \text { are North Platte blocks and sp are South Platte blocks. }\end{array}$ \\
\hline$\underline{\text { REPORT }}$ & $\begin{array}{l}\text { Directory contains this report, Appendix I (2009 poster, Abraham } \\
\text { and others), Appendix II (2009 poster, Smith and others) and } \\
\text { Appendix III (contractor's report). }\end{array}$ \\
\hline DEPTHSEC & $\begin{array}{l}\text { Directory contains the databases of the inverted depth section for } \\
\text { the } 2008 \text { and } 2009 \text { surveys in western Nebraska. }\end{array}$ \\
\hline CRESCENTLAKE & $\begin{array}{l}\text { Directory contains plots, gis files, and geotiffs for Crescent Lake } \\
\text { survey. }\end{array}$ \\
\hline
\end{tabular}




\section{Helicopter Electromagnetic and Magnetic Survey}

\section{Method and Measurements}

Kirsch (2006) and Rubin and Hubbard (2005) give good overviews of geophysical principles and applications to groundwater studies. Airborne geophysical surveys are usually made along regularly spaced flight lines within specified survey areas (fig. 1). Flight lines can be as close as $50 \mathrm{~m}$, though closer spacing is possible in special circumstances. The USGS has generally flown HEM surveys with 200-400-m spacing (1/8 to 1/4 mile; Smith and others, 2007), though flight lines with $800-\mathrm{m}$ separation have been used to map regional structures in a carbonate aquifer setting (Smith and others, 2008c). Table 2 gives the flight line specifications for each survey area.

Table 2. Flight line direction and spacing for each survey area. Flight lines are numbered according to block. For example, block 1 flight lines are numbered 10010, 10020 , and so on.

[m, meter; km, kilometer]

\begin{tabular}{|l|l|c|c|c|c|r|r|r|}
\hline Block & \multicolumn{1}{|c|}{ Area } & $\begin{array}{c}\text { Traverse } \\
\text { azimuth }\end{array}$ & $\begin{array}{c}\text { Tie line } \\
\text { azimuth }\end{array}$ & $\begin{array}{c}\text { Traverse } \\
\text { line } \\
\text { spacing }\end{array}$ & $\begin{array}{c}\text { Tie line } \\
\text { spacing } \\
(\mathrm{m})\end{array}$ & $\begin{array}{c}\text { Traverse } \\
\text { line }(\mathrm{km})\end{array}$ & $\begin{array}{c}\text { Tie line } \\
(\mathrm{km})\end{array}$ & $\begin{array}{c}\text { Total } \\
(\mathrm{km})\end{array}$ \\
\hline 1 & NP Area 1 & $360^{\circ}$ & $090^{\circ}$ & $400 \mathrm{~m}$ & NA & 247.2 & 5.7 & 252.9 \\
\hline 2 & NP F-lines & Variable & NA & NA & NA & 279.3 & NA & 279.3 \\
\hline 3 & SP F-lines 3 & Variable & NA & NA & NA & 105.9 & NA & 105.9 \\
\hline 4 & SP F-lines 4 & Variable & NA & NA & NA & NA & NA & NA \\
\hline 5 & SP Area 5 & $54^{\circ}$ & NA & $1300 \mathrm{~m}$ & NA & 16.7 & NA & 16.7 \\
\hline 6 & SP Area 6 & $64^{\circ}$ & NA & $400 \mathrm{~m}$ & NA & 81.1 & NA & 81.1 \\
\hline 7 & Crescent L. & $341^{\circ}$ & $071^{\circ}$ & $200 \mathrm{~m}$ & 15,895 & 48.9 & 1.1 & 50.0 \\
\hline 8 & $\begin{array}{l}\text { Re-flight of } \\
\text { 08 L40037 }\end{array}$ & $121^{\circ}$ & NA & NA & NA & 3.8 & NA & 3.8 \\
\hline TOTAL & & & & & & & & 937.1 \\
\hline
\end{tabular}


The main part of the geophysical system is housed in a cylindrical tube or "bird" that is towed beneath the helicopter. In the system flown by Fugro Airborne Ltd., all of the measurement systems in the bird are transmitted by a cable to a processing and digital recording system in the helicopter. Electromagnetic (EM) and total field magnetic airborne geophysical data measurements are made approximately every $3 \mathrm{~m}$ along the flight line. Figure 3 shows the instrumentation used for HEM surveys similar to that used for this survey.

\section{Electromagnetic Measurements}

The principles of HEM methods are summarized by Siemon (2006) and Paine and Minty (2005). The RESOLVE ${ }^{\mathcal{O}}$ HEM system flown by Fugro Airborne, Ltd., is described in detail in Appendix III. The EM measurements are made using six coil pairs that measure EM signals at separate frequencies from about 400 hertz to about 115,000 hertz $(115 \mathrm{kHz})$. Five of the coil pairs were oriented in a horizontal, coplanar position, and one of the coil pairs was oriented in a vertical, coaxial position. The specific frequencies, separation, and orientation of the coil pairs are given in table 3.

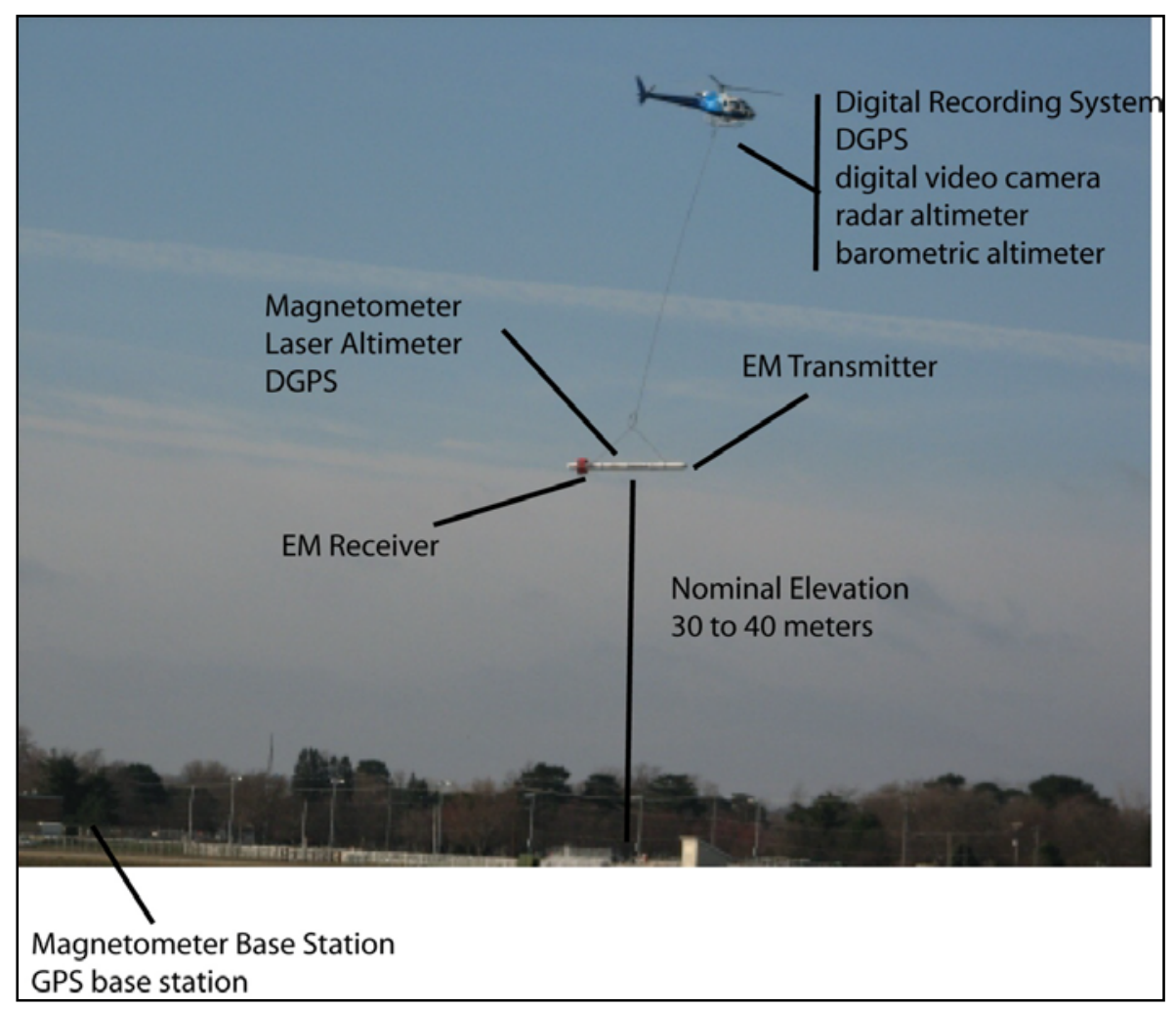

Figure 3. Helicopter-borne Resolve geophysical system similar to that used in the Nebraska survey: Electromagnetic, magnetic, GPS and laser altimeter sensors are housed in a "bird", a cigar-shaped 9-meter-long tube, which is kept at approximately 30-40 meters above ground. 
Table 3. Frequencies and measurement sensitivities for the HEM survey. The coil pair separation is 7.9 meters for all except for the 3,300-hertz coil-pair, which is 9.0 meters.

\begin{tabular}{|c|c|c|c|}
\hline Coil configuration & $\begin{array}{c}\text { Nominal } \\
\text { frequency } \\
\text { (hertz) }\end{array}$ & $\begin{array}{c}\text { Actual } \\
\text { frequency } \\
\text { (hertz) }\end{array}$ & $\begin{array}{c}\text { Sensitivity } \\
\text { (parts per million) }\end{array}$ \\
\hline Coplanar & 400 & 395 & 0.12 \\
\hline Coplanar & 1,800 & 1822 & 0.12 \\
\hline Coaxial & 3,300 & 3,262 & 0.12 \\
\hline Coplanar & 8,200 & 8,199 & 0.24 \\
\hline Coplanar & 40,000 & 38,760 & 0.60 \\
\hline Coplanar & 140,000 & 128,755 & 0.60 \\
\hline
\end{tabular}

The EM measurements made approximately every $3 \mathrm{~m}(10 \mathrm{ft})$ along flight lines are reduced to apparent resistivity values, as described in the contractor's report (Appendix III). One important consideration of the HEM Earth subsurface imaging is that the depth of imaging is dependent on the frequency and resistivity of the Earth. One estimate of the depth of exploration (depth of mapping) for the frequencies used in the $\operatorname{RESOLVE}^{\mathscr{C}}$ system is shown in figure 4. In this figure, the depth of exploration is defined as 0.5 of the skin depth (point at which a plane electromagnetic wave has attenuated to 37 percent of the initial amplitude). The depths of exploration estimates shown in figure 4 are conservative because one skin depth generally is considered to be the depth limit of HEM measurements (Fraser, 1978). Generally, at the highest frequency, depths of exploration are just a few meters. At the lowest frequency, $400 \mathrm{hertz}$, the depth of exploration may be on the order of $80 \mathrm{~m}$. This aspect of HEM resistivity measurements is the basic principle that allows depth images to be constructed. Additional discussion of the depth of investigation can be found in a subsequent section on EM data inversion. 


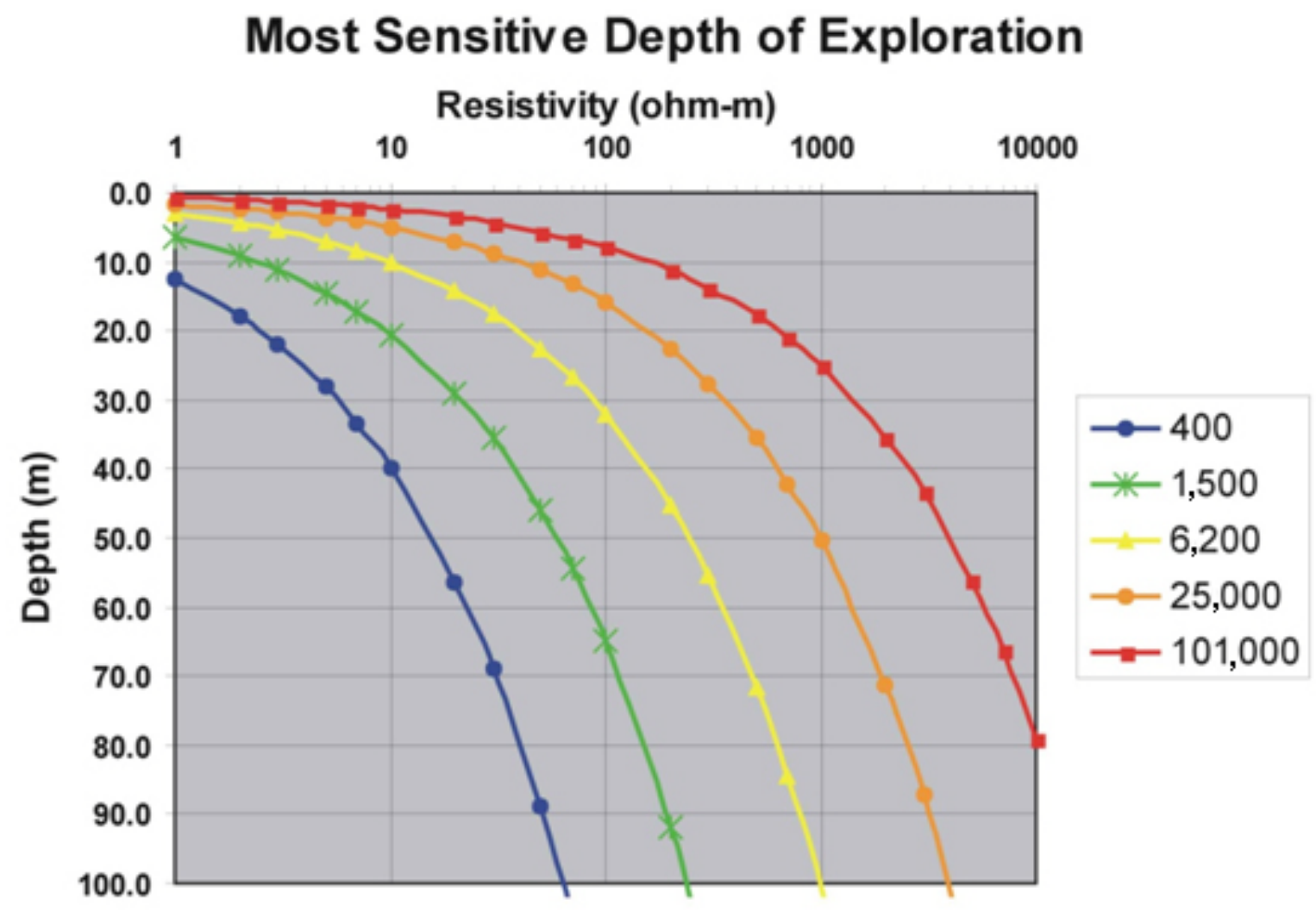

Figure 4. Depth of penetration or imaging as a function of frequency and Earth resistivity for the RESOLVE@ system (Greg Hodges, Fugro Airborne Ltd., written communication, 2004).

The EM signals are recorded for each frequency as in-phase and quadrature (out-of-phase) as referenced to the transmitted signal. These signals are postprocessed to apparent resistivity for each frequency and a corresponding apparent depth as described in Appendix II and by Fraser (1978). The apparent resistivity is, as the name implies, not the intrinsic electrical resistivity of the Earth but a value estimated based on assumptions of the measurement and of a homogeneous earth (Fraser, 1978). Estimates of the intrinsic resistivity are obtained through a variety of imaging methods that are described by Siemon (2006) and Hodges (2004). The differential resistivity and depth transformation (Huang and Fraser, 1996) is one simple depth imaging method that has proven effective for HEM survey data (Smith and others, 2003). Both the apparent resistivity and differential data are given in the digital line data files (see readme file in LINEDATA folder). 
An important part of the data processing is leveling the EM signals for system drift and calibrations. The specific steps used in the data processing are described in Appendix III. The digital line data give the raw in-phase and quadrature data and the processed data from which the apparent resisitivites are computed. The final leveled data are also provided. These data are included in the database in case the original data are used for reprocessing.

\section{Total Magnetic Field Measurements}

The HEM survey used a magnetic system (Appendix III) that measures the Earth's total magnetic field to an accuracy of 0.01 nanotesla (nT). The magnetic field consists of the Earth's main magnetic field and the local magnetic field due to sources within the crust and ferromagnetic metallic sources at the surface. The total field measurements are influenced by short-term variations in the magnetic field that are independent of local sources and are caused mainly by solar activity. A total magnetic field base station, set up by the contractor near the base of operations, is used to record these short term variations in the Earth's total magnetic field, which are subtracted from the measurements made during the survey.

Sharma (2002) describes the basic principles of the main magnetic field removal from magnetometer measurements. The contractor also processed the total magnetic field to remove the spatial variation from the Earth's main magnetic field. This spatial variation is defined by the International Geomagnetic Reference Field (IGRF).

\section{Ancillary Measurements}

The airborne electromagnetic system also monitors 60-hertz signals in coaxial and coplanar coil configurations. The data are given as CXPL CPPL channels in the line database (LINEDATA). The data are given as arbitrary voltage levels, which generally increase over power lines. The expression of power lines is quite variable due to a number of factors such as the size of the line, how well it is "grounded," and the electrical resistivity of the Earth. In general the infrastructure around urban development, transmission towers, and along major roads has a higher cultural noise level resulting in high 60-hertz signals.

Positioning measurements of the bird and the helicopter are critical in processing and making accurate maps. Location data from the GPS system in both the bird and helicopter are given in the files in the LINEDATA folder. Elevation data from the laser altimeter on the bird as well as the radar and barometric altimeters on the helicopter are given in the LINEDATA files. An important aspect of the contractor's data processing is the elevation data, which are given in the World Geodetic System of 1984 (WGS84) spheroid and have not been reduced to an ellipsoid. The contractor's report explains that additional processing needed to do this data reduction was not part of the USGS contract. 


\section{Inversion of Electromagnetic Data}

Abraham and others (2009, and Appendix II) describe the application of inversion of HEM data to obtain resistivity-depth estimates along flight lines that then can be interpreted in hydrologic model parameters. The multifrequency HEM data are inverted using the code EM1DFM (Farquharson, 2000; Farquharson and others, 2003). This is a 1-D nonlinear least-squares algorithm that recovers the distribution of electrical conductivity (reciprocal of resistivity) with depth beneath each sounding. The inversion algorithm minimizes an objective function $(\Phi)$ that is a combined measure of data misfit $\left(\phi_{d}\right)$ and model norm $\left(\phi_{m}\right)$ given by

$$
\Phi=\phi_{d}+\beta \phi_{m} .
$$

Inversion of HEM data is ill-posed and nonunique; that is, many resistivity models are consistent with the measured data, and some form of regularization is needed to stabilize the inverse problem. Regularization is introduced through the model norm, which favors specific properties in the inverted model such as proximity to a reference model or smoothness. The relative importance of fitting the data compared to controlling the model through regularization is controlled by a tradeoff parameter, $\boldsymbol{\beta}$. Details on how $\boldsymbol{\beta}$ was chosen for the inversions in this study are discussed below.

The data misfit component of the objective function describes how well the observed data match the data predicted by the inverted resistivity model. Specifically, it is defined as the L2norm of the difference between observed and predicted data, normalized by the data error, for each frequency.

$$
\phi_{d}=\left\|W_{d}\left(d^{o b s}-d^{\text {pred }}\right)\right\|^{2}
$$

The data weighting operator, $W_{d}$, is a diagonal matrix with entries $\boldsymbol{\sigma}_{f}^{-1}$, where $\boldsymbol{\sigma}_{f}$ is the standard deviation of the noise for each frequency. Specification of the data errors is an important, but often overlooked, aspect of the inverse problem. Set too low, the algorithm will tend to fit noise in the data and result in models with too much structure. Set too high, the algorithm can easily fit the data with many models, and the resulting models are strongly controlled by the regularization term. Data errors used for inversion with the 2008 and 2009 datasets were taken from the Fugro report for each survey and are summarized in table 4. 
Table 4. Fugro-specified data errors for the 2008 and 2009 HEM surveys.

$[\mathrm{Hz}$, hertz; ppm, parts per million]

\begin{tabular}{|c|c|c|c|}
\hline \multicolumn{2}{|c|}{2008} & \multicolumn{2}{|c|}{2009} \\
\hline Frequency (Hz) & $\begin{array}{c}\text { Data error } \\
\text { (In-phase and } \\
\text { quadrature, ppm) }\end{array}$ & Frequency (Hz) & $\begin{array}{c}\text { Data error } \\
\text { (In-phase and } \\
\text { quadrature, ppm) }\end{array}$ \\
\hline 385 & 5 & 395 & 10 \\
\hline 1,793 & 10 & 1,822 & 10 \\
\hline 3,345 & 10 & 3,262 & 10 \\
\hline 8,171 & 10 & 8,199 & 20 \\
\hline 41,020 & 20 & 38,760 & 40 \\
\hline 129,550 & 40 & 128,755 & 50 \\
\hline
\end{tabular}

The model norm component of the objective function is a combined measure of proximity to a reference model and smoothness.

$$
\boldsymbol{\phi}_{m}=\boldsymbol{\alpha}_{s}\left\|m-m^{r e f}\right\|^{2}+\boldsymbol{\alpha}_{z}\|\nabla m\|^{2}
$$

The scaling terms $\boldsymbol{\alpha}_{s}$ and $\boldsymbol{\alpha}_{z}$ control the relative importance given to proximity to the reference model and model smoothness, respectively. Because $\boldsymbol{\beta}$ scales both $\boldsymbol{\alpha}_{s}$ and $\boldsymbol{\alpha}_{z}$, it is only important to specify the relative weight of these latter terms, which is often simplified by setting one of them to 1 .

\section{Testing to Determine Optimal Inversion Parameters}

Before inverting the HEM datasets, a series of parameter tests was carried out on a test line extracted from the dataset to determine the optimal starting model, reference model, and tradeoff parameters $\boldsymbol{\beta}, \boldsymbol{\alpha}_{s}$, and $\boldsymbol{\alpha}_{z}$. All of the inversions were parameterized with a 25-layer model, where the depth to the top of the underlying half-space was $125 \mathrm{~m}$. The thicknesses of each layer, automatically assigned by EM1DFM, are summarized in table 5 . 
Table 5. Layer thicknesses used for HEM inversions.

\begin{tabular}{|l|l|}
\hline Layer & Thickness \\
\hline 1 & 0.860682 \\
\hline 2 & 0.976045 \\
\hline 3 & 1.10687 \\
\hline 4 & 1.25523 \\
\hline 5 & 1.42348 \\
\hline 6 & 1.61427 \\
\hline 7 & 1.83064 \\
\hline 8 & 2.07602 \\
\hline 9 & 2.35428 \\
\hline 10 & 2.66984 \\
\hline 11 & 3.02769 \\
\hline 12 & 3.43351 \\
\hline
\end{tabular}

\begin{tabular}{|l|l|}
\hline 13 & 3.89372 \\
\hline 14 & 4.41562 \\
\hline 15 & 5.00747 \\
\hline 16 & 5.67866 \\
\hline 17 & 6.43980 \\
\hline 18 & 7.30297 \\
\hline 19 & 8.28183 \\
\hline 20 & 9.39189 \\
\hline 21 & 10.6507 \\
\hline 22 & 12.0783 \\
\hline 23 & 13.6973 \\
\hline 24 & 15.5332 \\
\hline 25 & half-space \\
\hline
\end{tabular}

The starting model was selected by computing the best-fitting half-space for each sounding along the test line. The median value was approximately 0.0333 siemen per meter $(30 \mathrm{ohm}-$ meters), which is used for the starting model and base reference model for all subsequent runs.

In order to select the tradeoff parameters, multiple inversions were run using all possible combinations of $\boldsymbol{\beta}=\left[\begin{array}{l}1050100 \\ 0\end{array}, \boldsymbol{\alpha}_{s}=\left[\begin{array}{l}0.0010 .010 .1 \\ 0\end{array}\right.\right.$. For all cases, $\boldsymbol{\alpha}_{s}$ was fixed at 1.0 because it is only the relative value of this parameter with respect to $\alpha_{s}$ that is important. In addition to the inversion runs with fixed values of $\beta$, an additional set of inversions were run using the same three values for $\boldsymbol{\alpha}_{s}$, but with the generalized cross validation (GCV) criterion (Farquharson, 2000; Haber and Oldenburg, 2000) for automatically selecting an optimal value for $\beta$ at each sounding along the line. Use of the GCV method for selecting $\beta$ is more robust, but can sometimes result in significant model artifacts when there is unaccounted-for noise in the data.

Based on the inverted models using the above parameters, it was determined that the GCV method of automatically selecting $\beta$ produced the best results along the entire test line. The GCV method was particularly useful in selecting different values of $\beta$ that were best suited to sections of the test line with different subsurface structural properties (for example over deep, resistive channels). The best value for $\boldsymbol{\alpha}_{s}$ was chosen as 0.005 , based on observation of the test inversions using $\alpha_{s}=0.001$ and 0.01 . A summary of the complete set of inversion parameters used in EM1DFM is summarized in table 6. 
Table 6. Summary inversion parameters for use in EM1DFM.

\begin{tabular}{|l|l|}
\hline Model type & Conductivity only \\
\hline Starting conductivity model & $\begin{array}{l}\text { 25 layers, 125 m to top of halfspace, 30 } \\
\text { ohm-meters }\end{array}$ \\
\hline Base reference model & 30 ohm-meters \\
\hline Tradeoff parameter method & GCV \\
\hline Model norm components & $\mathrm{s}=0.005, \quad \mathrm{z}=1$ \\
\hline
\end{tabular}

\section{Model Assessment Using the Depth of Investigation (DOI) Metric}

The depth of investigation (DOI) metric (Oldenburg and Li, 1999) is a valuable tool for evaluating the approximate depth in an inverted model to which the data are sensitive. The DOI metric is defined as the difference between two models inverted with different reference models, divided by the difference in reference models

$$
D O I=\frac{m^{1}-m^{2}}{m_{0}^{1}-m_{0}^{2}} .
$$

Because EM1DFM solves for log-conductivity values, we use $m=\log _{10} \sigma$ to compute the DOI metric. Where the inverted models, $m^{1}$ and $m^{2}$, are strongly determined by the data (that is, shallow regions with greater sensitivity), $m^{1} \approx m^{2}$ and $D O I \rightarrow 0$. At depth where the data are not sensitive to the model parameters, regularization in the inverse problem forces the inverted model to be close to the reference model so that $m^{1} \approx m_{0}^{1}, m^{2} \approx m_{0}^{2}$, and $D O I \rightarrow 1$. Small values of the DOI metric, therefore, represent regions in the model that are most strongly determined by the data.

To compute the DOI metric, additional inversions are run with reference models $m_{0}^{1}=6$ ohm-meters and $m_{0}^{2}=150 \mathrm{ohm}$-meters, which are scaled by a factor of 5 from the base reference model of $30 \mathrm{ohm}$-meters. A cutoff value for the DOI metric is specified such that portions of the inverted models with DOI values greater than the cutoff are strongly influenced by the reference model. In this study, we use $D O I_{\text {cutoff }}=0.2$.

The DOI metric is a very useful tool when displaying the final inverted images because it provides a means for displaying areas of confidence in the model. In many instances, geophysical images are presented without any measure of where the models are determined by the data and where they are simply a reflection of the reference model. A simple approach is to completely blank-out regions in the model where $D O I>D O I_{\text {cutoff }}$, preserving only the parts of the model that are controlled by the measured data. 


\section{Digital Data}

Digital data are given in the folders described in table 1. The following describes the digital data in each subfolder.

\section{Metadata}

The METADATA folder contains files that describe geophysical survey blocks (fig. 1). These survey blocks are the boundaries for line data, digital grids, and plots. The metadata also describe the projection used for all of the digital plots which is North American Datum of 1983 (NAD83) Universe Transverse Mercator Zone 13 North (UTM13N) (meters).

\section{GIS Data}

The GIS folder contains various files that may be useful in map preparation. The flight line location files are in dxf (AUTOCAD). Outlines for each survey area are given as ESRI shape files (.shp and ancillary files).

\section{Grids}

Flight line data are interpolated onto a regular grid (gridded) to produce map plots. One of the challenges of gridding airborne geophysical data is that the spacing between flight lines is much greater than the sampling along the line (a few meters). Specialized gridding methods have been developed to deal with this aspect of processing airborne geophysical data (Smith and O'Connell, 2005). The contractor has used a modified Akima spline method (Appendix III). The contractor grids are given in the GRIDS folder in the FUGRO subfolder. These grids have not been modified. The nomenclature for the grid names is given in the readme.txt file.

An alternate gridding method is the minimum curvature method implemented by Webring (1981) for geophysical airborne data. This gridding method is used in the GEOSOFT OASIS MONTAJ program (http://www.geosoft.com/resources/papers/pdfs/topicsingriddingworkshop.pdf). We have used this algorithm to produce grids from selected channels of the flight line data. These grids can be found in the subfolder USGS. The grid cell size was $75 \mathrm{~m}$. File naming convention is given in the readme.txt file. The USGS grids also include the magnetic data, digital elevation, and powerline monitor data. These grids have $75-\mathrm{m}$ cell size. The grids can be viewed in free software distributed by GEOSOFT

(http://www.geosoft.com/pinfo/oasismontaj/free/montajviewer.asp). Plug-ins for various mapping software packages can be found on the GEOSOFT Web site (http://www.geosoft.com/downloads/). Plots produced from the grid files are described in the plots section. 
The grids can be imported into ESRI ArcMap applications with a plug-in provided by GEOSOFT (http://www.geosoft.com/resources/releasenotes/plugins/arcGISplugin.asp). A sample display of one such plot in ArcMap is shown in figure 5. Color scale bars can be imported to match those of the geoTIFF maps. The grids may need to be given specific projection information (NAD83 UTM13N) depending on the base maps that are used.

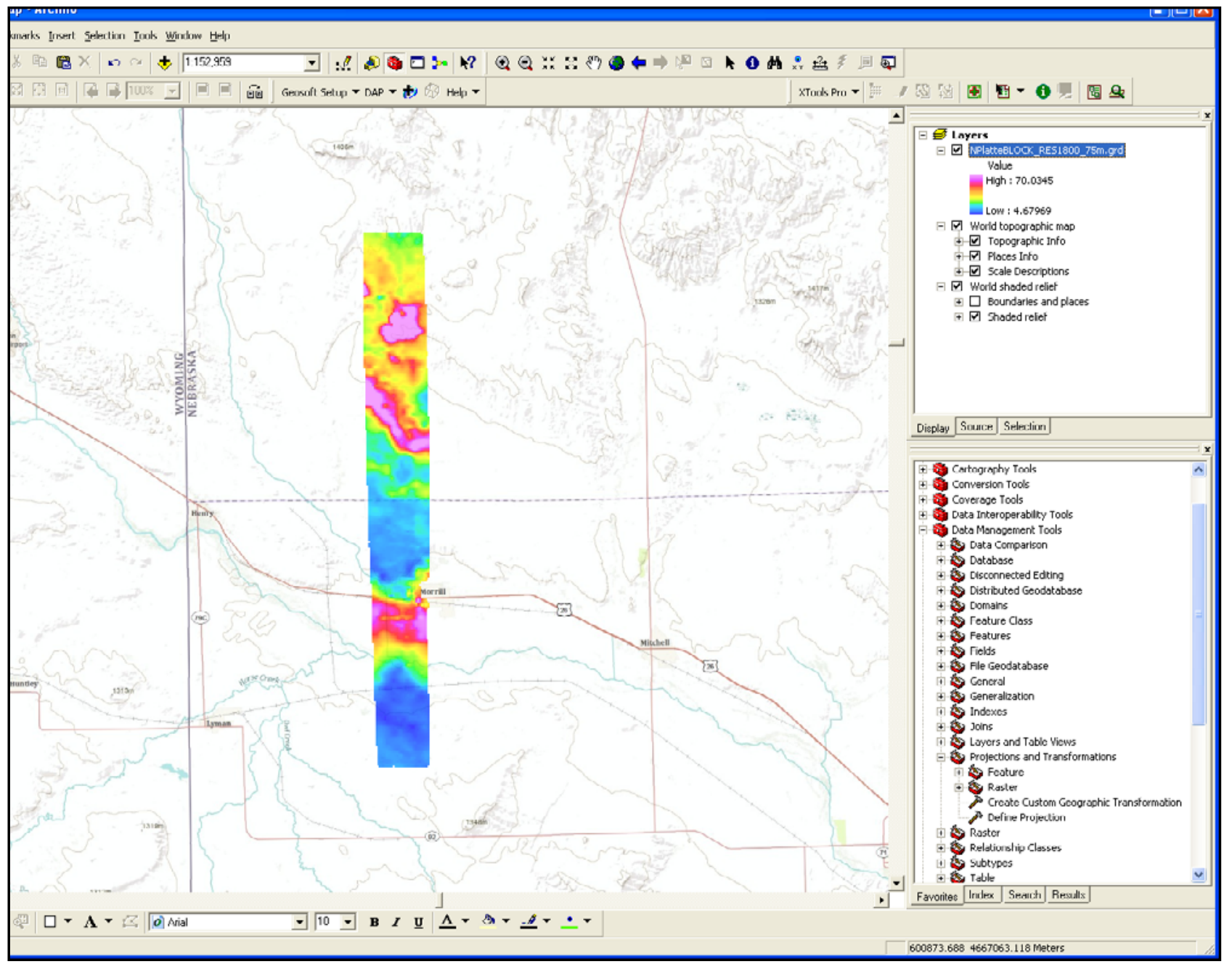

Figure 5. Screen shot of ArcMap plot of GEOSOFT grid for the 2008 Morril Block. Note the GEOSOFT plugin is displayed in the toolbar. The background topographic relief map is displayed using data added by Internet servers. The toolbox display in the lower left shows the projection tool that might be needed to properly define the projection of the grid. 


\section{Plots}

The USGS has produced plots (PLOTS folder) of the gridded data described previously as PDF files (PDF folder) and georeferenced TIFF format (GEOTIFF folder) files. The projection used for the GEOTIFF plots is the same as the grids, NAD83 UTM13N. The plot files have been produced with a color scale common to all frequencies for each survey area. Thus the colors for apparent resistivity maps can be directly compared between frequencies. Generally the apparent resistivity is higher by about $75 \mathrm{ohm}$ meters for the North Platte River area so a color scale with a slightly different range has been used than for the Lodgepole Creek area. The color scale gives high resistivity as warm colors (reds) and low resistivity as cool colors (blues).

\section{Digital Flight Line Data}

The flight line data for each area are given in the folder LINEDATA. The files are given in ascii format with column headings as described in the readme file. The contractor's report in APPENDIX III also describes the digital flight line data.

\section{Keyhole Markup Language (KML) Files}

KML is a file format used to display geographic data in an Earth browser such as Google Earth, Google Maps, and Google Maps for mobile devices. According to Wikipedia (http://en.wikipedia.org/wiki/Kml) KML was developed for use with Google Earth, which was originally named Keyhole Earth Viewer. It was created by Keyhole, Inc., which was acquired by Google in 2004. The name "Keyhole" is a homage to the KH reconnaissance satellites, the original eye-in-the-sky military reconnaissance system first launched in 1976. The KML files are released as compressed files (KMZ) which load into the Google Earth application.

Presentation of HEM data at an early public meeting of the NPNRD showed that there was interest in being able to show geophysical flight lines and data in Google Earth (GE) using KMZ files. Consequently, a set of files in this format have been included in this report. In the year that has passed since that meeting, interest has increased in use of GE as a platform for display of earth science maps and data. A special session at the 2009 American Geophysical Union and the keynote address of the meeting (Frontiers of Geophysics Lecture: The Spread of Scientific Knowledge From the Royal Society to Google Earth and Beyond, presented by Michael Jones, Chief Technical Officer, Google Earth; http://www.agu.org/webcast/fm08/) discussed use of GE in earth and planetary sciences. 
A user's guide to GE can be found at the following hyperlink:

(http://earth.google.com/intl/en/userguide/v5/). The display of flight lines and data can be accomplished by clicking the files in the KMZ folder (if a link has been established for this file type) or by opening the $\mathrm{kmz}$ file in GE. A sample image of the GE displays is shown for a sample area near Sidney, Nebraska, in figure 6.

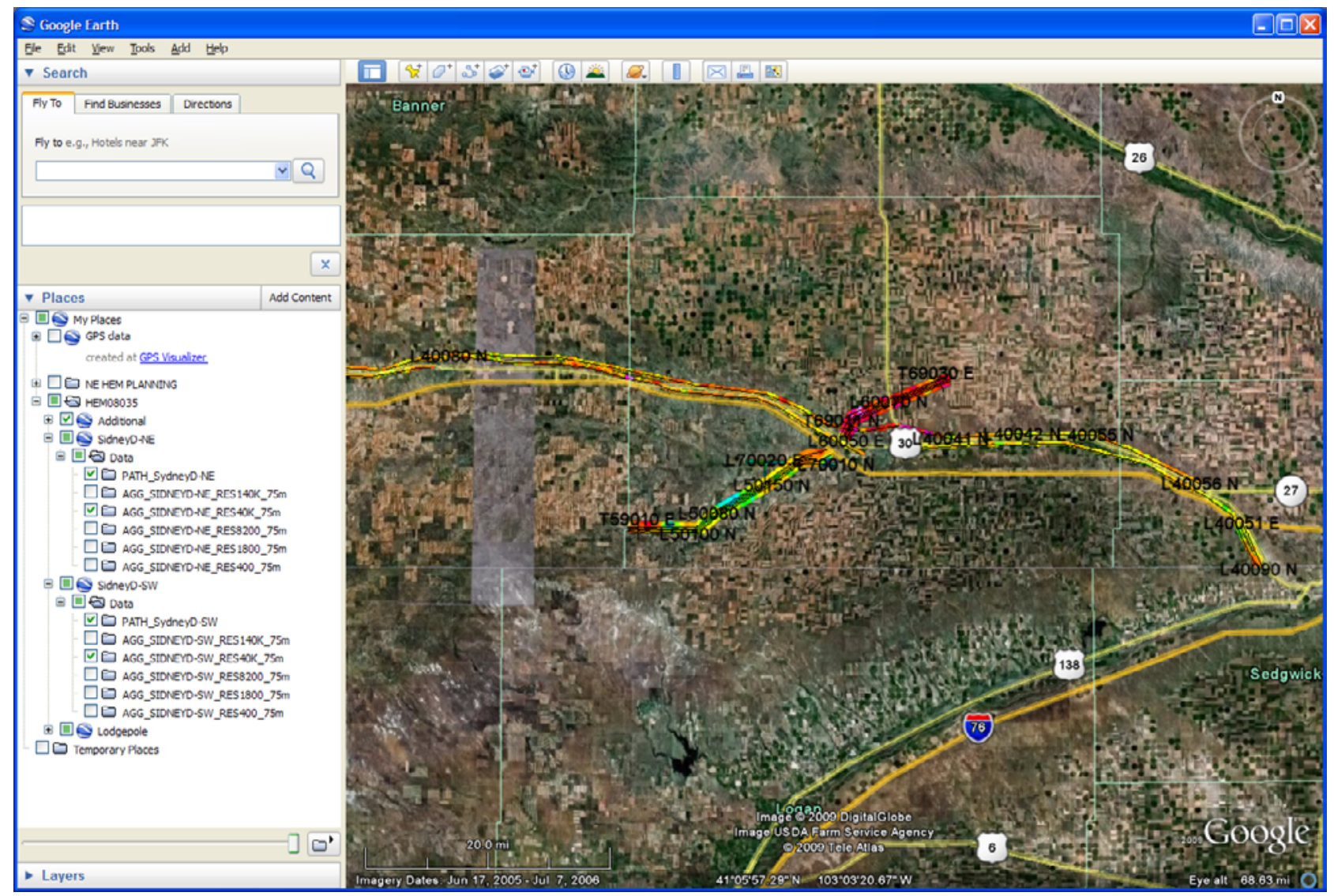

Figure 6. Screen capture of Google Earth map for the HEM survey in Sidney, Nebraska, area. The data shown are apparent resistivity at 40,000 hertz. Black lines are flight lines with selected flight line numbers shown. Note in the panel on the left of the display, various layers can be turned on and off. 


\section{Resistivity Depth Section Database}

The resistivity as a function of depth along the flight lines as determined from the depth imaging or inversion described previously is given in folder DEPTHSEC. One important aspect of the plotting of depth sections is plotting the corresponding elevations. As described in the Fugro report (Appendix III), the elevation data from the GPS and laser altimeter have not been projected in an orthometric datum. The laser altimeter gives the distance about Earth's surface only.

Elevation data are provided relative to two datums. In the electromagnetic and magnetic databases, radar altimeter values were subtracted from the differentially corrected and de-spiked GPS values to provide land-surface elevations above the WGS84 ellipsoid along survey lines (Appendix III). These elevations are available only along survey lines and are not consistent with the datum being used by water-resource managers and groundwater modelers in the Nebraska panhandle. To facilitate comparison of the inverted resistivity profiles to other data, such as borehole lithology and geophysical logs, and to make future interpretations more immediately useful for local studies, elevations in the inverted resistivity databases have been sampled from preexisting digital elevation models. Ten-meter resolution digital elevation models produced in cooperation between the U.S. Geological Survey and the Nebraska Department of Natural Resources (accessed April 2010 at: http://www.dnr.state.ne.us/databank/dbindex.html) were converted to the NAD83 and provide elevations in meters relative to the National Geodetic Vertical Datum of 1929 (NGVD29).

It is critical, in using the depth data given in the databases, to check projections or use digital elevations from other models being used.

\section{Acknowledgments}

The authors thank Ron Cacek, Manager, North Platte Natural Resources District (NPNRD), and Rod Horn, Manager, South Platte Natural Resources District (SPNRD), for coordination of financial and material support of the hydrogeophysical program. In particular, the NPNRD took the lead in contracting the airborne geophysical survey. We also recognize Kay Grote and Don Ogle, public relations and education officers for the NP and SP NRDs, for help in announcements and coordination with media and public safety offices. Roy Lyles (NP) for coordination of field efforts, Jeff Sprock (NP) and Kyle Liebig (SP) provided insight for developing useful formats for the geophysical data to facilitate applications to GIS aspects of the NRD programs. Funding for the Crescent Lakes flight was provided by the USGS Office of Groundwater through the Groundwater Resources Program. Michelle Johnson provided USGS GIS support through planning and data release parts of the project. The authors would also like to thank the following personnel of Fugro Airborne Surveys for their insight and technical support with organizing, collecting, processing, 
and interpreting the HEM data: Greg Hodges, Geophysicist, Dima Amine, Contract Liaison, Lesley Minty, Project Manager, Amanda Heydorn, Field Geophysicist/Crew Leader, Chris Tucker, Pilot (Great Slave Helicopters Ltd.), Paul A. Smith, Interpretation Geophysicist, Richardo White, Geophysical Data Processor, and Lyn Vanderstarren for drafting and geophysical flight line layouts.

\section{References Cited}

Abraham, J.D., Bedrosian, P.A., Ball, L.B., Cannia, J.C., Minsley, B.J., Peterson, S.M., and Smith, B.D., 2009, Quantitative hydrogeological framework interpretations from modeling helicopter electromagnetic survey data, Nebraska panhandle: Eos Transactions, AGU, v. 90, no. 52, Fall Meeting Supplement, Abstract H53B-0929, 1 p.

Abraham, J.D., Cannia, J.C., Peterson, S.M., Smith, B.D., Minsley, B.J., and Bedrosian, P.A., 2010, Using airborne geophysical surveys to improve groundwater resource management models: Proceedings, Symposium on the Application of Geophysics to Engineering and Environmental Problems, Environmental and Engineering Geophysical Society, 10 p.

Cannia, J.C., Abraham, J.A., Smith, B.D., Steele, G.V., and Korus, J.T., 2007, Preliminary results of hydrogeological framework studies of surface water-Ground water systems in eastern Nebraska using airborne and ground geophysics: Geological Society of America Abstracts with Programs, v. 39, no. 6, p. 162.

Cannia, J.C., Woodward, D., and Cast, L.D., 2006, Cooperative hydrologic study cohyst, hydrostratigraphic units and aquifer characterization report, accessed June 2, 2009, at http://cohyst.dnr.ne.gov/document/dc012hydro_aquifer_022406.pdf.

Farquharson, C.G., 2000, Background for program "EM1DFM": University of British Columbia Geophysical Inversion Facility, Vancouver, Canada. 20 p. (accessed August, 2010 at http://www.eos.ubc.ca/ubcgif/iag/sftwrdocs/em1dfm/bg.pdf).

Farquharson, C.G., Oldenburg, D.W., and Routh, P.S., 2003, Simultaneous 1D inversion of loop-loop electromagnetic data for magnetic susceptibility and electrical conductivity:

Geophysics, v. 68, no. 6, p. 1857-1869.

Fraser, D.C., 1978, Resistivity mapping with an airborne multicoil electromagnetic system: Geophysics, v. 43, p. 144-172.

Haber, E., and Oldenburg, D., 2000, A GCV based method for nonlinear ill-posed problems: Computational Geosciences, v. 4, no. 1, p. 41-63.

Hodges, G., 2004, Practical inversions for helicopter electromagnetic data: Proceedings, Symposium on the Application of Geophysics to Engineering and Environmental Problems, Environmental and Engineering Geophysical Society, 10 p. 
Huang, H., and Fraser, D.C, 1996. The differential parameter method for muiltifrequency airborne resistivity mapping: Geophysics, v. 55, p.1327-1337

Kirsch, R., 2006, Groundwater geophysics - A tool for hydrogeology: Springer-Verlag, Berlin, Heidelberg, 489 p.

Loope, D. B., Swinehart, J.B., and Mason, J.P.,1995, Dune-dammed paleovalleys of the Nebraska Sand Hills intrinsic versus climatic controls on the accumulation of lake and marsh sediments: Geological Society of America Bulletin v. 107, p. 396-406.

Oldenburg, D.W., and Li, Y., 1999, Estimating depth of investigation in de resistivity and IP surveys: Geophysics, v. 64, no. 2, p. 403-416.

Paine, J.G., and Minty, B.R.S., 2005, Airborne hydrogeophysics, in Rubin, Yoram, and Hubbard, S.S., eds., Hydrogeophysics: The Netherlands, Springer, Water Science and Technology Library, v. 50, p. 333-357.

Rubin, Y., and Hubbard, S. S., 2005, Hydrogeophysics: The Netherlands, Springer, Water Science and Technology Library, v. 50, 523 p.

Sharma, P.V., 2002 (reprinted), Environmental and Engineering Geophysics; Cambridge University Press, 472 p.

Siemon, B., 2006, Electromagnetic methods-Frequency domain airborne techniques, in Kirsch, R., ed., Groundwater geophysics - A tool for hydrogeology: Springer-Verlag, Berlin, p. $155-170$.

Smith, B.D., Abraham, J.A., Cannia, J.C., and Hill, P., 2009, Helicopter electromagnetic and magnetic geophysical survey data for portions of the North Platte and Lodgepole Creek, Nebraska, June 2008: U.S. Geological Survey Open-File Report 2009-1110, 28 p.

Smith, B.D., Abraham, J.A., Cannia, J.C., Steele, G.V., and Hill, P., 2008a, Helicopter electromagnetic and magnetic geophysical survey data, Oakland, Ashland, and Firth study areas, eastern Nebraska, March 2007: U.S. Geological Survey Open-File Report 20081018, 31 p., 1 plate

Smith, B.D., Abraham, J.A., Cannia, J.C., Steele, G.V., and Peterson, S.M., 2008b, Helicopter electromagnetic surveys for hydrological framework studies in Nebraska: Eos Transactions, AGU, v. 89 no. 53, Fall Meeting Supplement, Abstract NS43B-1190, 1 p.

Smith, B.D., Blome, C.D., Smith, D.V., Scheirer, D.D., and Deszcz-Pan, M., 2008c, Geophysical surveys to characterize the hydrogeology of the Arbuckle Uplift, south-central Oklahoma: Symposium on Environmental and Engineering Geophysics, Philadelphia. 2008 Annual Meeting Proceedings, p. 539-548. 
Smith, B.D., Cannia, J.C., and Abraham, J.D., 2010, Design of reconnaissance helicopter electromagnetic and magnetic geophysical surveys of the North Platte River and Lodgepole Creek, Nebraska: Eos Transactions, AGU, v. 90, no. 52, Fall Meeting Supplement, Abstract H53B-0930, 1 p.

Smith, B.D., Grauch, V.J.S., McCafferty, A. E., Smith, D.V., Rodriguez, B.R., Pool, D.R., DeszczPan, M., and Labson, V.F., 2007, Airborne electromagnetic and magnetic surveys for ground-water resources: a decade of study by the U.S. Geological Survey, in Proceedings of Exploration 07: Fifth Decennial International Conference on Mineral Exploration, edited by B. Milkereit, 2007, p. 895-899.

Smith, B.D., Irvine, R., Blome, C.D., Clark, A.K., and Smith, D.V., 2003, Preliminary results, helicopter electromagnetic and magnetic survey of the Seco Creek area, Medina and Uvalde Counties, Texas: Proceedings for the Symposium on the Application of Geophysics to Environmental and Engineering Problems, 15 p.

Smith, B.D., Thamke, J.N., Cain, M.J., Tyrrell, C., and Hill, P.L., 2006, Helicopter electromagnetic and magnetic survey maps and data, East Poplar oil field area, Fort Peck Indian Reservation, northeastern Montana, August 2004: U.S. Geological Survey Open-File Report 2006-1216, 23 p., 1 plate.

Smith, R.S., and O'Connell, M.D., 2005, Interpolation and gridding of aliased geophysical data using constrained anisotropic diffusion to enhance trends: Geophysics, v. 70. no. 5, p 121127.

Steele, G.V., Sibray, S.S., and Quant, K.A., 2007, Evaluation of ground water near Sidney, Nebraska, 2004-05: U.S. Geological Survey Scientific Investigations Report 2007-5086, $54 \mathrm{p}$.

Weeks, J.B., Gutentag, E.D., Heimes, F.J., and Luckey, R.R., 1988, Summary of the High Plains regional aquifer-system analysis in parts of Colorado, Kansas, Nebraska, New Mexico, Oklahoma, South Dakota, Texas, and Wyoming: U.S. Geological Survey Professional Paper 1400-A, 30 p.

Webring, Michael, 1981, MINC: A gridding program based on minimum curvature: U.S. Geological Survey Open-File Report 81-1224, 12 p.

Won, I.J., 1990, Diagnosing the Earth: Ground-water monitoring review, summer 1990: National Ground Water Association, 2 p. 


\section{APPENDIX I: American Geophysical Union Poster}

Framework Interpretations from Modeling Helicopter Electromagnetic Survey Data, Nebraska Panhandle

The poster is provided in the REPORTS folder as HEM_AGU_poster_Abraham_20091209.pdf. 


\section{APPENDIX II: American Geophysical Union Poster}

Helicopter Electromagnetic Surveys for Hydrological Framework Studies in Nebraska

The poster is provided in the REPORTS folder as HEM_AGU_poster_Smith_20091209.pdf. 


\section{APPENDIX III: Fugro Geophysical Report}

The contractor's report (08034rep.pdf) is given in the REPORTS folder. 